Dept. of Vet. Medicine, Faculty of Vet. Med., Assiut Univ., Head of Dept. Prof. Dr. I.S.A. Abdallah.

\title{
EFFECT OF SYNANTHIC (OXFENDAZOLE) AGAINST NATURAL INFESTATION OF SHEEP WITH GASTRO-INTESTIMAL PARASITES (With Two Tables)
}

\author{
By \\ M.I. MOURAD; LAILA SALAH and A.A. AMER \\ (Received at 4/3/1989)
}

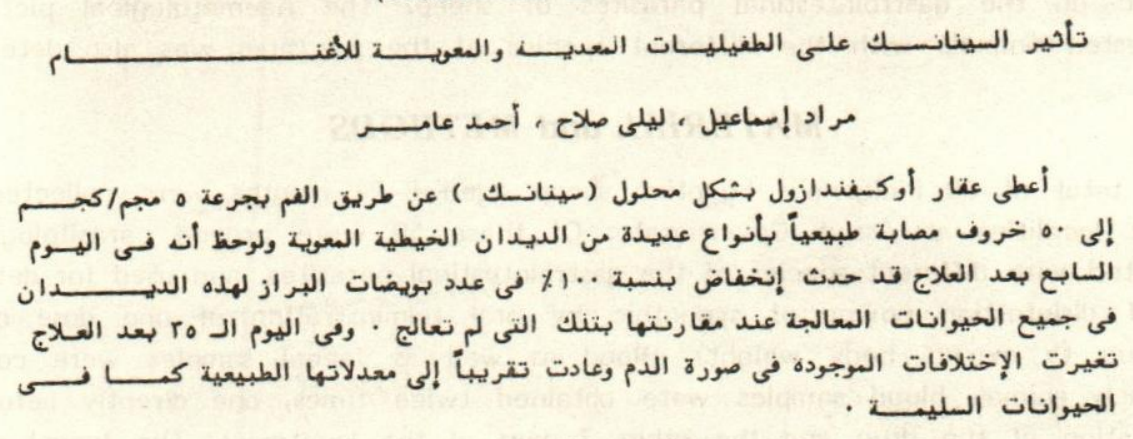

\section{SUMMARY}

* Synanthic (oxfendazole) suspention as one of the broad spectrum antiheleminths drug was orally administered in a dose of $5 \mathrm{mg} / \mathrm{kg}$ body weight to 50 naturally infested sheep of ( $8-24$ months age) with gastrointestinal parasites.

The faecal parasitic egg count ceased completely after 7 days post administration of synanthic drug.

The haemogram picture retained to its normal level after 35 days of treatment.

\section{INTRODUCTION}

Worm infestation is considered one of the most important troubles of our domestic farm animals. Treatment of the infested animals with medicaments is one of the most reliable method for controling such infestation.

The occurrence of different genera and species of helminth parasites in stomach and intestines of sheep was studied by many authors allover the world. The most important genera recoverd were Ostertagia spp., and Trichostrongylus. Haemonchus, Strongyloides, Cooperia, Nematodirus spp., N. battus, Bunostomum, Chabertia, Trichuris and Oesphagostomum were less frequently occur, (MARTIN, 1983).

* Produced by Mycofarm Ireland LTD, Ballyboggan industrial Estate, Dublin II. 
M.l. MOURAD, et al.

Field trails on disinfestation showed that oxfendazole in a dose $5 \mathrm{mg} / \mathrm{kg}$ has beneficial effect on removal of all round as well as tape worms from sheep at all ages and under varying climatic and husbundary conditions (LEIMBACHER, et al. 1976; BAKER and FISK, 1977; DOWNEY, 1977). It was also found to be good effect against common gastrointestinal round worms, lung worms and tapeworms (Monezia spp) of Cattle (AVERKIN, et al. 1975; CHALMERS, 1977, 1978 and DOWNEY, 1976).

The present investigation was performed in order to estimate the efficiancy of synanthic on the gastrointestinal parasites of sheep. The haematological picture of the infested animals with the different species of the parasites was also determined.

\section{MATERIAL and METHODS}

A total of 60 indigenous Egyptian sheep aged 8-24 months were collected from different localities at Assiut Governorate. Of these 50 were proved parasitological to be infested with different species of the gastrointestinal parasites, and used for determination of disinfesting power of synanthic by oral adminstration of one dose only of such drug ( $5 \mathrm{mg} / \mathrm{kg}$. body weight). Blood as well as faecal samples were collected from each animal, blood samples were obtained twice times, one directly before the adminstration of the drug and the other 7 days of the treatment. The faecal samples were collected weekly for 5 weeks.

The other 10 sheep were used as control. Of these five are infested with the internal parasite and the other proved to be free of infestation with such parasite.

\section{Haematological examination:}

Blood samples were collected from the jugular vein of each animal. Bottles containing "E.D.T.A." Ethylene diamine tetera acetic acid, as anticoagulant were used for collection of such samples, Haematological picture of each animal, total leucocytic (T.W.B.Cs), total erthrocytic (T.R.B.Cs) count, packed cell volum "P.C.V", Haemoglobin content, "HB", and differential leucocytic count were determined according to SCHALM (1979).

\section{Parasitological investigation:}

Faecal samples were collected from each animal before and after 7, 14, 27, 28, 35 days of adminstring synanthic drug. Small plastic bags were used for collection of faecal specimens, flotation and sedmentation technique, (BENBROOK and SLOSS (1955) was adapted.

III. Statistical analysis of the obtained data was performed according to the method of snedecor and COCHRAN (1967).

\section{RESULTS}

Are presented in Tables $1 \& 2$. 


\section{EFFECT OF SYNANTHIC ON PARASITES OF SHEEP}

\section{DISCUSSTION}

It is clearly evident from our results that sheep were infested with varying degrees by different species of parasities including Trichostrongylus, ostertagia, Haemonchus, Nematodirus, Chabertia and Ascaris. The avarage number of parasitic eggs was found to be 850 pergram of faecal matter.

Periodical faecal examination of the treated sheep with the oral adminestrations of one dose synanthic ( $5 \mathrm{mg} / \mathrm{kg}$ body weight) reaveled that the gastrointestinal worm eggs ceased completely after 7 days of treatment. Consequently the signs of the parasitic infestation including severe emaciation, diarrhoea, depraved appetite, pale mucous membrane, botle jaw, week and rapid heart beats and roughened coat had markedly disappeared from treated animals as compared with those used as control. This is clearly evident after 35 days from adminestratio of synanthic, a result which are mainly altributed to the lethal effect of such drug on Helminth parasites.

The results tabulated in Table (1) showed a high significant variation in Total erythrocytic count and haemoglobin content between both healthy and infested sheep this obtained data is more or less similar to that recorded by BLUNT (1975). On the other hand leucocytosis associated with both esinophilia and monocytosis were observed in the infested sheep as compared with the healthy ones, a result which is coinside with that previously recorded by COLES (1980).

Table I \& II also indicate that the haemogram picture of diseased animals returned to its normal value 35 days after treatment, same results were observed in goats by MICHAEL, et al. (1979) but after two months.

From the resutls acheived we can safely conclude that the oral adminestration of one dose of synanthic ( $5 \mathrm{mg} / \mathrm{kg}$ B.wt), was found to be fo lethal effect on the helminth parasites of sheep.

\section{REFERENCES}

Averkin, E.A.; Beard, C.C.; Dvorak, C.A.; Ed. Wards, J.A.; Fried, J.H.; Kilian, J.G.; Schiltz, R.A.; Kistner, T.P.; Drrudge, J.H.; Lyons, E.T.; Sharp, M.L. and Corwin, R.M. (1975): J. of Medical chemistry 18, (11): 1164-11,66.

Baker, N.F. and Fisk, R.A. (1977): American J. of Vet. Research, 38, (9): 1315-1316.

Benbrook, E.A. and Sloss, M.N. (1955): The Veterinary clinical. Parasitology, 2nd Ed. lowa, State press, U.S.A.

Blunt, M.H. (1975): Blood of sheep, camposition and Function spinger - Verlag, BerlinHeidelberg. New York.

Chalmers, K. (1977): Newzealand Vet. J., 25 (10): 266-269.

Chalmers, K. (1978): Neszealand Vet. J., 26: 162-164.

Coles, E.H. (1980): Vet. Clinical Pathology, 3rd Ed. W.B. Sounders, company philadelphia, London, 140-141. 
M.l. MOURAD, et al.

Downey, N.E. (1976): Vet. Record, 99: 267-270.

Downey, N.E. (1977): Vet. Record, 101 (3): 260-263.

Leimbacher, F.; Nicholas, J.A. and Delahaye, J. (1976): Revue medicale et veterinaire 127 (6): 941-957.

Martin, W.B. (1983): Diseases of sheep Black well scientific publication Oxford, London, Edinburgh Boston Melbourne, 56-62; 250-255.

Michael, S.A.; Higgins, A.J. and El-Refau, A.H. (1979): Trop. Animal. Hlth. Prod., 11: 63-68.

Schalm, O.W. (1979): Vet. haematology 4th Ed. Balliere Tindall \& Camel Ltd London, 47-123.

Snedecor, G.W. and Cochran, W.G. (1967): Statistical methods. 6th Ed. lowa State Collage Pass lowa, U.S.A.

Table (1)

Blood picture in case of infested \& non infested sheep

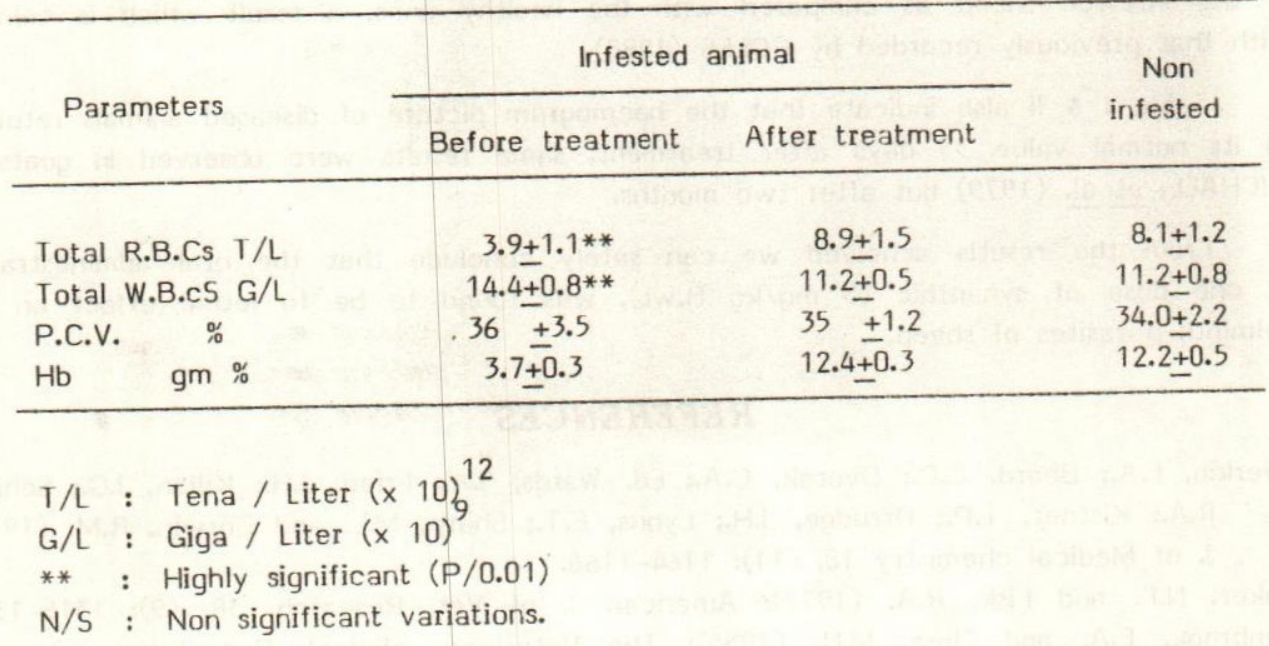




\section{EFFECT OF SYNANTHIC ON PARASITES OF SHEEP}

Table (2)

Differential leucocytic count in case of infested and non infested sheep

\begin{tabular}{|c|c|c|c|}
\hline \multirow{2}{*}{ Parameters } & \multicolumn{2}{|c|}{ Infested animals } & \multirow{2}{*}{ Non infest } \\
\hline & Before treatment & After treatment & \\
\hline Band cell \% & $3.7 \pm 0.5$ & $5.8 \pm 2.3$ & $3.5 \pm 0.2$ \\
\hline Neutrophil \% & $29.8 \pm 0.6$ & $30 \pm 1.2$ & $32.5 \pm 0.5$ \\
\hline Esoin $\%$ & $11.3 \pm 0.5 * *$ & $8.1 \pm 2.1$ & $6.9 \pm 0.5$ \\
\hline Lymph & $46.8 \pm 0.4$ & $47.9 \pm 0.1$ & $49.6 \pm 1.3$ \\
\hline Mono & $12.1 \pm 0.8 * *$ & $8.2 \pm 1.2$ & $7.5 \pm 0.5$ \\
\hline
\end{tabular}

